Crop Breeding and Applied Biotechnology 12: 253-260, 2012

Brazilian Society of Plant Breeding. Printed in Brazil

\title{
ARTICLE
}

\section{Effect of selection on genetic variability in yellow passion fruit}

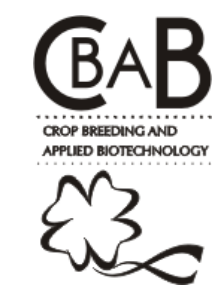

Juliana Leles Costa $^{1}$, Onildo Nunes de Jesus ${ }^{2}$, Gilmara Alvarenga Fachardo Oliveira ${ }^{1}$ and Eder Jorge de Oliveira ${ }^{2 *}$

Received 12 June 2012

Accepted 15 September 2012

\begin{abstract}
The objective of this study was to evaluate the genetic diversity in improved (IG) and unimproved germplasm (UIG) of yellow passion fruit (Passiflora edulis Sims f. flavicarpa Deg), based on ISSR (Inter Simple Sequence Repeat) markers. The genotypes were grouped by neighbor joining clustering and principal component analysis. Regardless of the genotype, a high number of polymorphic bands was observed, aside from several specific fragments of the groups, according to the level of improvement. Unimproved genotypes had a higher number of polymorphic fragments. The hierarchical and principal component clustering coincided in the formation of two rather distinct groups (IG and UIG). The molecular analysis of variance to check the differentiation between groups showed 57 and $43 \%$ of the variation within and between groups, respectively. This study demonstrated the potential of ISSR to determine molecular polymorphism in yellow passion fruit and that breeding has narrowed the genetic variability.
\end{abstract}

Key words: Breeding, molecular markers, ISSR, germplasm, Passiflora.

\section{INTRODUCTION}

The family Passifloraceae comprises 630 species distributed in tropical regions of America, Asia and Africa. The geographic distribution of the genus Passiflora, native to South America, is wide in central and northern Brazil (Vanderplank 1996). The species of this genus have a high medicinal, ornamental and mainly commercial value, particularly P. edulis Sims. f. flavicarpa Deg. (yellow passion fruit), which is the most widely grown and accepted on the fruit market (Freitas et al. 2011).

The challenges for the development of new varieties of passion fruit are huge, because the irregular production, low yields and high disease incidence, mainly, need improvement. In this context, the variability of the plant material to be improved is essential to increase and maintain genetic gains throughout the various selection cycles. Low variability in the base population and high selection intensity narrow the genetic variability and consequently reduce genetic gains in subsequent cycles. When estimating the genetic variability and selection impact in two cycles of recurrent selection of yellow passion fruit based on microsatellite markers (SSR), Reis et al. (2011) found an increased inbreeding, slight loss of variability and small changes in allele frequencies in the two cycles. In different accessions of yellow passion fruit, assessed with RAPD - Random Amplified Polymorphic DNA (Viana et al. 2003), ISSR - Inter Simple Sequence Repeat (Santos et al. 2011) and morphoagronomic descriptors (Crochemore et al. 2003), no significant genetic variability was observed, indicating a possible narrowing of the genetic basis of some commercial cultivars.

The maintenance of genetic variability in breeding populations should be monitored at various stages of improvement, to ensure a successful and uninterrupted development of new varieties with increased yield, fruit quality and disease resistance. Advances in biotechnology and genomics offer the possibility of a gradual change from phenotypic to genotypic selection and therefore, the possibilities of using tools of biotechnology and genomics in this process are numerous (Reis et al. 2011).

Molecular markers, which access the variability directly at the DNA level, are not affected by environmental influences, do not depend on the plant development stage and are ideal to detect inter and intraspecific molecular polymorphism. Among the various types of potentially useful molecular

\footnotetext{
Universidade Federal do Recôncavo da Bahia, Campus Universitário de Cruz das Almas, 44.380-000, Cruz das Almas, BA, Brazil

2 Embrapa Mandioca e Fruticultura, Rua Embrapa, s/nº C.P. 007, 44.380-000, Cruz das Almas, BA, Brazil. *E-mail: eder@cnpmf.embrapa.br
} 
markers for yellow passion fruit, the ISSR are especially important because they allow a rapid genotyping on agarose gels, exploiting polymorphism in microsatellite regions without the need for DNA sequencing, with genome-wide coverage, combining the advantages of SSR and AFLP with the universality of RAPD (Zietkiewicz et al. 1994, Reedy et al. 2002). This marker has been successfully used in the analysis of genetic diversity of several fruit trees, such as Poncirus trifoliata (Fang et al. 1997), citrus (Fang and Roose 1997), banana (Godwin et al. 1997), grape (Wu et al. 2009), and yellow passion fruit (Santos et al. 2011).

Regardless of the goals and methods of improvement and the inherent self-incompatibility of yellow passion fruit, leading to allogamy and therefore the existence of genetic variability, the selection of genotypes with greater phenotypic uniformity will always narrow the genetic base. Depending on the origin of the genetic material and the degree of selection, the loss of alleles can negatively affect the maintenance of the productive potential of improved genotypes. Comparative studies between improved genotypes and germplasm accessions are essential to verify the distribution of genetic variability, changes in allele frequencies and the direction of allelic losses, to outline the best strategy of crop improvement. The purpose of this study was to evaluate the potential of ISSR markers in yellow passion fruit breeding and to assess the effect of genetic diversity in two sets of genotypes obtained by different breeding methods (massal selection, hybrids and half-sib progenies), in comparison to unimproved germplasm accessions.

\section{MATERIAL AND METHODS}

\section{Plant material}

From the breeding program of Embrapa Cassava and Fruit (PMGM - CNPMF), 63 yellow passion fruit genotypes were used, of which 20 were germplasm accessions of the Active Germplasm Bank of Passion fruit (UIG), 11 genotypes from massal selection among BAG-passion fruit accessions (IG), 19 half-sib families derived from a recurrent selection program (HSP), 12 hybrids obtained from a partial diallel (HYB) and one was a commercial hybrid, BRS Gigante Amarelo (BRS-GA) (Table 1).

\section{DNA extraction and genotyping of ISSR marlers}

The DNA was extracted from the accessions following a protocol described by Doyle and Doyle (1987), with some modifications, using CTAB (cetyltrimethylammonium bromide). The DNA samples of each of the 63 genotypes were extracted from a pool of 10 plants. DNA was quantified in $1.0 \%$ agarose gel $(\mathrm{w} / \mathrm{v})$ stained with ethidium bromide $(1.0$
Table 1. List of yellow-passion fruit accessions genotyped with ISSR markers

\begin{tabular}{|c|c|c|}
\hline Genotype & Provenance & Origin \\
\hline $\begin{array}{l}\text { GP09-01, GP09-02, } \\
\text { GP09-03, GP09-04, } \\
\text { GP09-05, GP09-06, } \\
\text { GP09-07, GP09-08, } \\
\text { GP09-09, GP09-10, } \\
\text { and GP09-11 }\end{array}$ & $\begin{array}{l}\text { Massal } \\
\text { Selection }^{1}\end{array}$ & CNPMF \\
\hline BGM007 & Exchange & UNESP \\
\hline BGM017 & Jaboticabal (SP) & UNESP \\
\hline BGM022 & Field collection & Cruz das Almas (BA) \\
\hline BGM023 & Field collection & Mogi-Guaçu (SP) \\
\hline BGM028 & Field collection & Nova Soure (BA) \\
\hline BGM033 & Exchange & IAPAR \\
\hline BGM041 & Field collection & Monte Alto (SP) \\
\hline BGM044 & Exchange & CENARGEN \\
\hline BGM051 & Field collection & Janaúba (MG) \\
\hline BGM064 & Field collection & $\begin{array}{l}\text { Conceição } \\
\text { do Jacuípe (BA) }\end{array}$ \\
\hline BGM076 & Field collection & Cruz das Almas (BA) \\
\hline BGM092 & Field collection & $\begin{array}{l}\text { Livramento Nossa } \\
\text { Senhora (BA) }\end{array}$ \\
\hline BGM116 & Exchange & Instituto Plantarum \\
\hline BGM140 & Field collection & Cruz das Almas (BA) \\
\hline BGM168 & Exchange & Instituto Plantarum \\
\hline BGM185 & Exchange & ESALQ \\
\hline BGM208 & Exchange & ESALQ \\
\hline BGM222 & Field collection & Salvador (BA) \\
\hline BGM229 & Field collection & Campinas (SP) \\
\hline BGM311 & Field collection & Nova Viçosa (BA) \\
\hline $\begin{array}{l}\text { A17, B19, B20, C02, } \\
\text { G16, H02, I02, I08, } \\
\text { J18, J20, K07, K08, } \\
\text { K20, L03, L06, L07, } \\
\text { L21, M17 and M20 }\end{array}$ & $\begin{array}{l}\text { Recurrent } \\
\text { selection }^{2}\end{array}$ & CNPMF \\
\hline $\begin{array}{l}\text { HS209-01, HS209-02, } \\
\text { HS209-03, HS209-04, } \\
\text { HS209-05, HS209-06, } \\
\text { HS209-07, HS209-08, } \\
\text { HS209-09, HS209-10, } \\
\text { HS209-11 and } \\
\text { HS209-12 }\end{array}$ & Hybrid $^{3}$ & CNPMF \\
\hline BGM325 (BRSGA) & Hybrid & CPAC \\
\hline
\end{tabular}

${ }^{1}$ Genotypes from massal selection in accessions of BAG-Yellow passion fruit; ${ }^{2}$ Varieties from a recurrent selection program within and between half-sib progenies; ${ }^{3}$ Hybrids from a cross in a partial diallel among parents with high agronomic performance, mainly for yield and fruit quality.

$m g \mathrm{~L}^{-1}$ ), using as standard Lambda phage DNA concentrations (Invitrogen), diluted to a final concentration of $2.5 \mathrm{ng} \mathrm{uL}^{-1}$.

Twenty-three ISSR primers were used (Table 2). The amplification reaction was performed in a final volume of 15 $\mathrm{uL}$, containing $10 \mathrm{ng}$ of genomic DNA; $20 \mathrm{mM}$ Tris - $\mathrm{HCl}$ (pH 8.4); $50 \mathrm{mM} \mathrm{KCl;} 1.5 \mathrm{mM}$ (Mix1) or $2.5 \mathrm{mM}$ (Mix3) $\mathrm{MgCl} 2 ; 0.2 \mathrm{mM}$ dNTP; $0.3 \mathrm{uM}$ of each primer; and $1 \mathrm{U}$ Taq DNA Polymerase (Invitrogen). 
Table 2. List of the total number of bands (NTB), number of polymorphic bands (NBP), percentage of polymorphism and polymorphic information content (PIC) in the analysis of ISSR markers

\begin{tabular}{|c|c|c|c|c|c|c|}
\hline Primer & Sequence* & $\mathrm{Ta}^{* *}$ & NTB & NBP & $\begin{array}{l}\% \text { of } \\
\text { polymor- } \\
\text { phism }\end{array}$ & PIC \\
\hline DiCA3'G & $(\mathrm{CA})_{8} \mathrm{G}$ & 48 & 18 & 18 & 100.0 & 0.22 \\
\hline DiCA3'RG & $(\mathrm{CA}){ }_{8} \mathrm{RG}$ & 48 & 12 & 12 & 100.0 & 0.18 \\
\hline DiCA3'YG & $(\mathrm{CA})_{8} \mathrm{YG}$ & 48 & 11 & 11 & 100.0 & 0.26 \\
\hline DiGA3'C & $(\mathrm{GA})_{8} \mathrm{C}$ & 48 & 9 & 9 & 100.0 & 0.22 \\
\hline DiGA3'RC & $(\mathrm{GA})_{8} \mathrm{RC}$ & 48 & 17 & 17 & 100.0 & 0.24 \\
\hline DiGA3’T & $(\mathrm{GA})_{8} \mathrm{~T}$ & 48 & 16 & 16 & 100.0 & 0.29 \\
\hline TriCAC3'RC & $(\mathrm{CAC})_{5} \mathrm{RC}$ & 48 & 14 & 14 & 100.0 & 0.39 \\
\hline TriCAC3'YC & $(\mathrm{CAC})_{5} \mathrm{YC}$ & 48 & 13 & 12 & 92.3 & 0.22 \\
\hline TriCAC5'CY & $(\mathrm{CAC})_{5} \mathrm{CY}$ & 48 & 20 & 19 & 95.0 & 0.37 \\
\hline TriCAG3'RC & $(\mathrm{CAG})_{5} \mathrm{RC}$ & 45 & 6 & 6 & 100.0 & 0.36 \\
\hline TriGTG3'YC & $(\mathrm{GTG})_{5} \mathrm{YC}$ & 48 & 14 & 14 & 100.0 & 0.29 \\
\hline TriTGT3’’YC ${ }^{1}$ & $(\mathrm{TGT})_{5} \mathrm{YC}$ & 48 & 9 & 9 & 100.0 & 0.22 \\
\hline TriAAC $3^{\prime} \mathrm{RC}^{1}$ & $(\mathrm{AAC})_{5} \mathrm{RC}$ & 45 & 10 & 10 & 100.0 & 0.22 \\
\hline TriAAG 3'RC & $(\mathrm{AAG})_{5} \mathrm{RC}$ & 48 & 11 & 11 & 100.0 & 0.29 \\
\hline TriACG 3'RC & $(\mathrm{ACG})_{5} \mathrm{RC}$ & 48 & 11 & 11 & 100.0 & 0.35 \\
\hline TriAGA 3'RC & $(\mathrm{AGA})_{5} \mathrm{RC}$ & 48 & 8 & 8 & 100.0 & 0.35 \\
\hline TriTGG 3'RC & $(\mathrm{TGG})_{5} \mathrm{RC}$ & 48 & 2 & 2 & 100.0 & 0.39 \\
\hline TriCGA 3'RC & $(\mathrm{CGA})_{5} \mathrm{RC}$ & 48 & 15 & 15 & 100.0 & 0.32 \\
\hline TriCGC 3'RC & $(\mathrm{CGC})_{5} \mathrm{RC}$ & 48 & 14 & 14 & 100.0 & 0.33 \\
\hline TriGAC 3'RC & $(\mathrm{GAC})_{5} \mathrm{RC}$ & 48 & 7 & 7 & 100.0 & 0.22 \\
\hline TriGCA 3'RC & $(\mathrm{GCA})_{5} \mathrm{RC}$ & 48 & 12 & 12 & 100.0 & 0.37 \\
\hline TriGCC $3^{\prime} \mathrm{RC}^{1}$ & $(\mathrm{GCC})_{5} \mathrm{RC}$ & 48 & 6 & 0 & 0.0 & 0.00 \\
\hline TriGGA 3'RC & $(\mathrm{GGA})_{5} \mathrm{RC}$ & 48 & 11 & 11 & 100.0 & 0.29 \\
\hline Mean & & & 11.57 & 11.22 & 95.10 & 0.28 \\
\hline
\end{tabular}

${ }^{1}$ Mix 3 was used for the amplification of these primers and Mix 1 for the others (see Material and Methods);

"R $=\mathrm{A}, \mathrm{G} ; \mathrm{Y}=\mathrm{C}, \mathrm{T}$;

${ }^{* *}$ Primer annealing temperature

The amplification was performed in a thermocycler Applied Biosystems (Model Veriti), and consisted of one denaturation cycle at $94{ }^{\circ} \mathrm{C}$ for $5 \mathrm{~min} ; 35$ cycles at $94{ }^{\circ} \mathrm{C}$ for $40 \mathrm{~s} ; 45$ or $48{ }^{\circ} \mathrm{C}$ for 40 s (Table 2); $72{ }^{\circ} \mathrm{C}$ for $60 \mathrm{~s}$; and a final extension at $72{ }^{\circ} \mathrm{C}$ for $5 \mathrm{~min}$.

Electrophoresis was performed in 2\% agarose gel (w/v) ethidium bromide-stained for $2 \mathrm{~h}$ at 120 volt and analyzed under UV light. The fragment was determined with a $100 \mathrm{bp}$ DNA ladder (New England BioLabs) as molecular weight marker.

\section{Data analysis}

The ISSR markers were converted into binary data, where one (1) is attributed to presence and zero (0) to absence of bands. The polymorphic markers were analyzed for diversity based on the Simple Matching coefficient of similarity, using software Genes (Cruz 2008). Based on the dissimilarity matrix, software Mega 4.1 was used (Tamura et al. 2007) to construct the dendrogram using neighbor-joining clustering. The agreement of the distance matrix with the dendrogram was verified by the cophenetic correlation (CC). The principal coordinate analysis was also used to visualize the genotype clusters. The molecular variance was analyzed (AMOVA) by the decomposition of the main components of UIG, IG, HYB and HSP using software GenAlEx 6.1 (Peakall and Smouse 2006).

The polymorphic information content (PIC) was calculated as $P I C_{i}=2 f_{i}\left(1-f_{i}\right)$, where $i$ is the information of marker $i ; f_{i}$ is the frequency of the amplified allele (presence of bands) and $\left(1-f_{i}\right)$ is the frequency of null alleles (Roldan-Ruiz et al. 2000). The PIC was based on the mean of each primer combination.

\section{RESULTS AND DISCUSSION}

\section{ISSR Polymorphism}

Of the 23 ISSR primers tested, 22 detected polymorphism among the accessions (Table 2). The markers generated a total of 266 bands (mean of 11.56 bands per primer), of which 260 (97.74\%) were polymorphic fragments with sizes ranging from $220-2300 \mathrm{bp}$. The total number of bands varied from 2 to 20 for the primers TriTGG3'RC and TriCAC5'CY, respectively.

The ISSR analysis detected a high number of bands per primer and a low percentage of monomorphic markers, indicating high intraspecific genetic variability of the accessions. For other crops, this analysis also showed high polymorphism levels, ranging from 70.5 to $98 \%$ (Ge and Li 2001, Wu et al. 2009, Santos et al. 2011). Although ISSR analysis is not recommended for taxonomic studies of phylogeny, the high number of polymorphic bands made grouping for geographical origin and parentage possible (Wu et al. 2009).

According to Colombo et al. (1998), the number of primers and the bands identified in this study were enough to access the genetic variability of passion fruit, since between 7-30 primers that generate 50-200 polymorphic bands are sufficient to estimate genetic relationships within and between species.

Primers related to dinucleotide repeat microsatellites produced a higher number of polymorphic bands than trinucleotides (13.83 and 10.94 fragments per primer, respectively) (Table 2). However, the opposite was reported by Santos et al. (2011) for species of the genus Passiflora, in which trinucleotides were more polymorphic than dinucleotides (15.3 and 10.5 average alleles per primer, respectively). This indicates that these conclusions depend essentially 
JL Costa et al.

Table 3. Molecular variance analysis (AMOVA), considering four groups: improved germplasm, unimproved germplasm, Half-sib progenies and hybrids

\begin{tabular}{lccccc}
\hline Source of variation & df & SS & MS & Component of variance & Total variation (\%) \\
\hline Among Populations & 3 & 1170.110 & 390.037 & 24.097 & $57 \%$ \\
Within Populations & 59 & 1061.786 & 17.996 & 17.996 & $43 \%$ \\
\hline Total & 62 & 2231.896 & & 42.094 & $100 \%$ \\
\hline
\end{tabular}
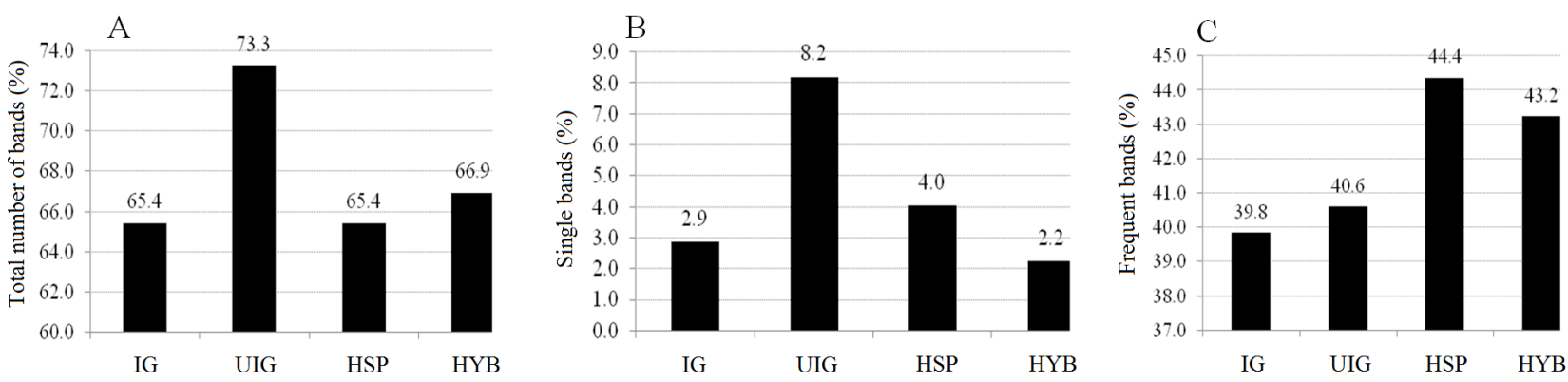

Figure 1. Percentage of the total number of bands (A), number of single bands (B), number of frequent bands ( $>70 \%$ of the accessions) $(\mathrm{C})$, in accessions of improved germplasm (IG), unimproved germplasm (UIG), half-sib progenies (HSP) and hybrids (HYB).

on the origin of the plant material and that the conclusions cannot be extrapolated to all situations.

Of the samples, the 20 unimproved germplasm accessions (UIG), 11 improved accessions (IG), 19 half-sib families (HSP), and the 12 hybrids (HYB) the percentage of the total bands was $73.3 \%$ (195) $66.9 \%$ (178) $65.4 \%$ (174), and 65.4\% (174), respectively (Figure 1a). Among all samples, unique haplotypes were identified for each group. The highest percentage of unique haplotypes (number of unique haplotypes/total bands per sample) was found in unimproved germplasm (UIG) with $8.2 \%$, followed by HSP, IG and HYB with $4.0 \%, 2.9 \%$ and $2.2 \%$, respectively (Figure $1 b)$. The greatest number of unique fragments was found in germplasm accessions, mainly the primers TriCAC5 ${ }^{\prime} \mathrm{CY}$ and DiCA 3' G, producing five and four bands, respectively. The unique fragments also evidence the polymorphism in P. edulis, since the accessions of the germplasm bank, for not having been selected directly, had more bands than the improved population. This means that if breeders are interested, the alleles lost by selection can be recovered by crosses with accessions of the germplasm bank of yellow passion fruit.

Using seven AFLP primer combinations in physic nut germplasm, Tatikonda et al. (2009) detected 59 unique fragments in a single accession and 108 in $10 \%$ of the studied population. This information is extremely useful to select the most divergent accessions in the early stages of breeding programs or even develop markers for varietal identification.

On the other hand, 218 bands were observed in over $70 \%$ of the accessions. Of these, 118 (44.4\%), $115(43.2 \%) 108$
(40.6\%), and $106(39.8 \%)$ are bands the accessions have in common with the half-sib families, hybrids, and with the unimproved and improved germplasm accessions, respectively (Figure 1c). This shows the similarity level and common alleles in accessions, especially for improved genotypes (particularly HSP and HYB) share a high number of alleles.

The polymorphic information content (PIC) for the 63 assessed genotypes ranged from 0.18 for DiCA3'RG to 0.39 for TriTGG3'RC, with a mean of 0.28 (Table 2). In contrast to the number of bands, the PIC values were higher for trinucleotides (average of 0.31 ) than for dinucleotides (average 0.24).

\section{Molecular variation and genotype clustering}

The genetic variability, as shown in the dissimilarity matrix data obtained by the Simple Matching index, ranged from 0.049 for the accessions GP09-07 vs GP09-04 to 0.407 for accessions BGM322 vs BGM140. In the dendrogram constructed by neighbor joining clustering, the cophenetic correlation (0.98) with the genetic distance matrix was high and therefore confirms the information of genotypic divergence based on the graphical representation of the dendrogram (Figure 2). Visual cluster analysis allowed the organization of the accessions in two major groups: one consisting of accessions comprising the germplasm (IG and BGM) and the other represented by hybrids and halfsib families of the breeding program (Figure 2). A similar behavior was observed in the principal component analysis (Figure 3), in which $74.59 \%$ of the total variation on the first axis separated the genotypes of the breeding program from those of BAG-Yellow passion fruit. 


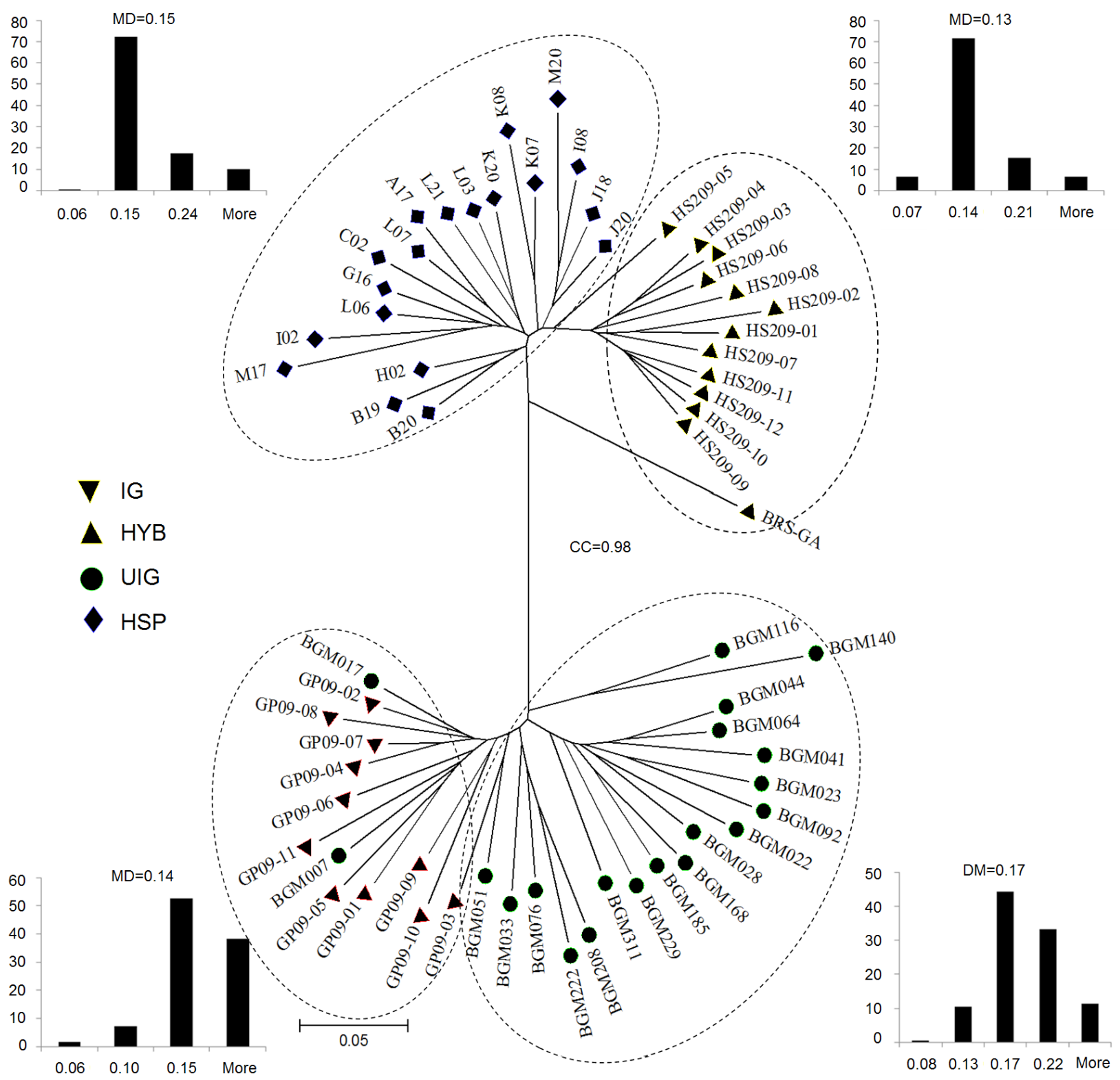

Figure 2. Dendrogram constructed by the neighbor-joining method, based on genetic dissimilarity among 63 accessions of yellow passion fruit, using ISSR markers. UIG = unimproved accessions; IG = improved accessions; BRS-GA = Gigante Amarelo; HYB = hybrids in test phase and HSP = halfsib progenies of a recurrent selection program. The distribution histograms are shown as proportion of the dissimilarity between pairs of accessions beside the clustered groups. MD: mean dissimilarity per group; CC: cophenetic correlation.

According to the distance matrix and the dendrogram, the germplasm accessions had the highest average dissimilarity $(0.17)$ and were grouped into different subgroups. The breeding program accessions however were grouped into three subgroups: HSP accessions, test hybrids (HYB) and BRS-GA. The HSP accessions were the most heterogeneous group, with a mean dissimilarity of 0.15 . Hybrid BRS-GA was the most divergent of the hybrids of the breeding program, probably due to a completely different geneal- ogy from the hybrids of the breeding program of Embrapa Cassava and Fruit. This hypothesis was reinforced by the 13 unique ISSR fragments of this hybrid. On the other hand, the variability of the hybrids (HYB) is probably lower (mean dissimilarity 0.13 ), because they have common parents in the diallel. However, some hybrids with high divergence within the cluster are still found, e.g., HS209-05, with a mean dissimilarity of 0.15 (Figures 2 and 3 ). 


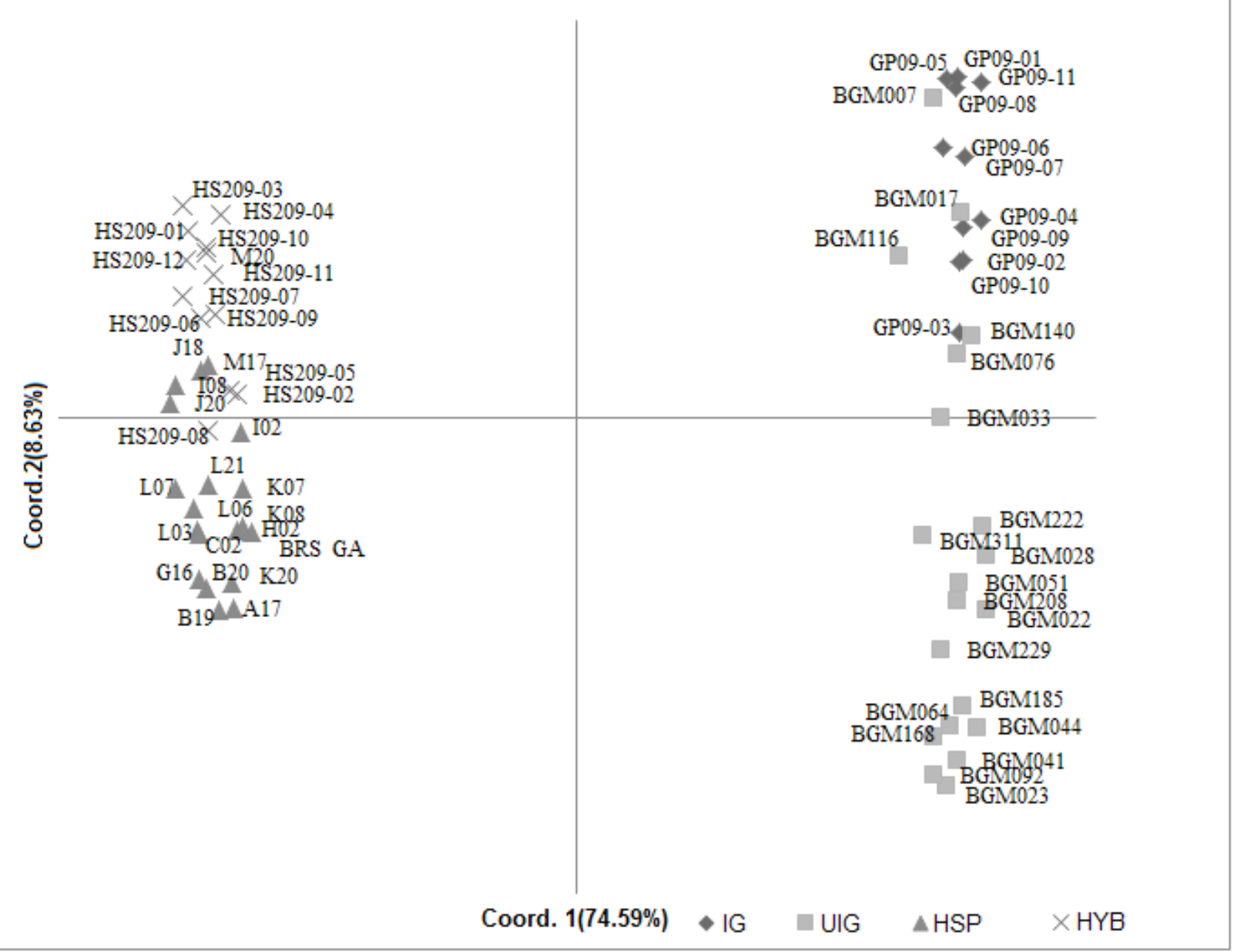

Figure 3. Principal Component Analysis of 63 accessions of $P$. edulis based on 23 ISSR primers. UIG $=$ unimproved accessions; IG $=$ improved accessions; $\mathrm{HYB}=$ hybrids in test phase and $\mathrm{HSP}=$ half-sib progenies of a recurrent selection program.

The percentage of genetic variability among the four groups (IG, BGM, HSP, and HYB) calculated by AMOVA showed most of the genetic variability among groups $(57 \%)$, indicating that the lower variability within groups (43\%) may be due to common alleles, owing to directional selection for certain agronomic plant traits. On the other hand, Zhang et al. (2012) compared cultivated with wild cacao genotypes in diversity studies and found greater genetic variation within groups $(81 \%)$ and that this diversity did not decrease after domestication. However, in the case of yellow passion fruit, the variability in the improved accessions was reduced. The findings of this study coincide with results obtained elsewhere, e.g., Li et al. (2010) identified a clear distinction between wild and domesticated soybean accessions.

In ginger (Curcuma amada), Jatoi et al. (2010) analyzed accessions from cultivated areas and from germplasm bank based on RAPD and functional genetic markers (analogous to P-450-PBA). The results indicated high polymorphism in the germplasm accessions ( $>91 \%$ ), and higher molecular variance in germplasm accessions than in the cultivated accession. However, in contrast to yellow passion fruit, molecular variation was highest within populations, with 85 and $93 \%$ for the analogous marker P-450-PBA and for RAPD, respectively. This shows that the variability may be associated with cocoa cultivation under different ecological conditions.

The greater genetic variability among accessions of BAG-Yellow passion fruit shows a wide genetic base of the species, with good prospects for breeding, since this diversity can be exploited to obtain new hybrids, as source of pest and disease resistance or to structure the germplasm in heterotic groups. Genetic diversity among accessions is due, among other factors, to the self-incompatibility system that favors cross-pollination and therefore the gene flow between the different genotypes (Ganga et al. 2004). 
Studies on genetic diversity are essential for the conservation and management of genetic resources in breeding programs (Tian-Ming et al. 2007) and in pre-breeding studies, to understand the parentage between genotypes, based on which crosses can obtain genetic gains in segregating generations (Viana et al. 2003, Ganga et al. 2004).

In general, ISSR markers can be valuable tools to study intraspecific genetic diversity in yellow passion fruit, since they allow the clustering of accessions according to the genetic origin. The accessions from the germplasm bank were grouped separately from the breeding program accessions, for containing greater diversity. On the other hand, the genotypes from the breeding program share more alleles than accessions of the germplasm bank, due, among other factors, to the direct selection of crosses which could result in changes in the frequency and loss of alleles.

\section{ACKNOWLEDGEMENTS}

The authors thank the Foundation for Research Support of the State of Bahia (Fapesb), Coordination for the Improvement of Higher Education Personnel (CAPES) and the National Council for Scientific and Technological Development (CNPq) for the financial support of the study and for the scholarships.

\section{Efeito da seleção na variabilidade genética em maracujazeiro amarelo}

Resumo - Objetivou-se avaliar a diversidade genética em germoplasma melhorado (IG) e não melhorado (G-NM) de maracujazeiro amarelo (Passiflora edulis Sims f. flavicarpa Deg), com o uso de marcadores do tipo ISSR (Inter Simple Sequence Repeats). Os genótipos foram agrupados pelo método de neighbor joining e por análise de componentes principais. Foi observado alto número de bandas polimórficas, independente do tipo de genótipo, além de diversos fragmentos específicos dos grupos, de acordo com o nível de melhoramento. Genótipos não melhorados apresentaram maior número de fragmentos polimórficos. O agrupamento hierárquico e de componentes principais foram concordantes na formação de dois grupos bem distintos (IG e G-NM). A análise de variância molecular, utilizada para verificar a diferenciação entre os grupos, evidenciou que 57 e 43\% da variação estão entre e dentro dos grupos, respectivamente. Este estudo evidenciou o potencial de uso dos ISSR na determinação do polimorfismo molecular em maracujazeiro amarelo e que o melhoramento tem reduzido a variabilidade genética.

Palavras-chave: Melhoramento, marcadores moleculares, ISSR, germoplasma, Passiflora.

\section{REFERENCES}

Colombo C, Second G, Valle TL and Charrier A (1998) Genetic diversity characterization of cassava cultivars (Manihot esculenta Crantz) with RAPD markers. Genetics and Molecular Biology 21: 105-113.

Crochemore ML, Molinari HB and Stenzel NMC (2003) Caracterização agromorfológica do maracujazeiro (Passiflora spp.). Revista Brasileira de Fruticultura 25: 5-10.

Cruz CD (2008) Programa Genes: diversidade genética. Editora UFV, Viçosa, 278p.

Doyle JJ and Doyle JL (1987) Isolation of plant DNA from fresh tissue. Focus 12: 13-15.

Fang DQ and Roose ML (1997) Identification of closely related citrus cultivars with inter-simple sequence repeat markers. Theoretical and Applied Genetics 95: 408-417.

Fang DQ, Roose ML, Krueger RR and Federici CT (1997) Fingerprinting of trifoliate orange germplasm accessions with isozymes, RFLPs and inter-simple sequence repeat markers. Theoretical and Applied Genetics 95: 211-219.

Freitas JPX, Oliveira EJ, Neto AJC and Santos LR (2011) Avaliação de recursos genéticos de maracujazeiro-amarelo. Pesquisa Agropecuária Brasileira 46: 1013-1020.
Ganga RMD, Ruggiero C, Lemos EGM, Grili GG, Gonçalves MM, Chagas EA and Wickert E (2004) Diversidade genética em maracujazeiro amarelo utilizando marcadores moleculares fAFLP. Revista Brasileira de Fruticultura 26: 494-498.

Godwin ID, Aitken EAB and Smith LW (1997) Application of intersimple sequence (ISSR) markers to plant genetics. Electrophoresis 18: $1524-1528$.

Jatoi SA, Kikuchi A, Ahmad D and Watanabe KN (2010) Characterization of the genetic structure of mango ginger (Curcuma amada Roxb.) from Myanmar in farm and genebank collection by the neutral and functional genomic markers. Electronic Journal of Biotechnology. http://dx.doi.org/10.2225/vol13-issue6-fulltext-10

Li A and Ge S (2001) Genetic variation and clonal diversity of Psammochloa villosa (Poaceae) detected by ISSR Markers. Annals of Botany 87: 585-590.

Li Y-H, Li W, Zhang C, Yang L, Chang R-Z, Gaut BS and Qiu L-J (2010) Genetic diversity in domesticated soybean (Glycine max) and its wild progenitor (Glycine soja) for simple sequence repeat and singlenucleotide polymorphism loci. New Phytologist 188: 242-253.

Peakall R and Smouse PE (2006) Genalex 6: genetic analysis in Excel. Population genetic software for teaching and research. Molecular Ecology Notes 6: 288-295. 


\section{JL Costa et al.}

Reedy MP, Sarla N and Siddiq EA (2002) Inter-simple sequence repeat (ISSR) polymorphism and its application in plant breeding. Euphytica 128: 9-17.

Reis RV, Oliveira EJ, Viana AP, Pereira TNS, Pereira MG and Silva MGM (2011) Diversidade genética em seleção recorrente de maracujazeiro amarelo detectada por marcadores microssatélites. Pesquisa Agropecuária Brasileira 46: 51-57.

Roldan-Ruiz I, Calsyn E, Gilliland TJ, Coll R, Van Eijk MJT and De Loose M (2000) Estimating genetic conformity between related ryegrass (Lolium) varieties. 2. AFLP characterization. Molecular Breeding 6: 593-602.

Santos LF, Oliveira EJ, Silva AS, Carvalho FM, Costa JL and Padua JG (2011) ISSR Markers as a tool for the assessment of genetic diversity in Passiflora. Biochemical Genetics 49: 540-554.

Tamura K, Dudley J, Nei M and Kumar S (2007) MEGA4: Molecular Evolutionary Genetics Analysis (MEGA) software version 4. Molecular Biology and Evolution 24: 1596-1599.

Tatikonda L, Wani SP, Kannan S, Beerelli N, Sreedevi TK, Hoisington DA, Devi P and Varshney RK (2009) AFLP-based molecular characterization of an elite germplasm collection of Jatropha curcas L., a biofuel plant. Plant Science 176:505-513.
Tian-Ming H, Xue-Sen C, Zheng X, Jiang-Sheng G, Pei-Jun L, Wen L, Qing L and Yan W (2007) Using SSR markers to determine the population genetic structure of wild apricot (Prunusarmeniaca L.) in the Ily Valley of West China. Genetic Resources and Crop Evolution 54: 563-572.

Vanderplank J (1996) Passion flowers. MIT Press, Massachusetts, 224p.

Viana AP, Pereira TNS, Pereira MG, Amaral Jr AT, Souza MM and Maldonado JFM (2003) Diversidade genética entre genótipos comerciais de maracujazeiro-amarelo (P. edulis f. flavicarpa) e entre espécies de Passifloras nativas determinada por marcadores RAPD. Revista Brasileira de Fruticultura 25: 489-493.

Wu Z-L, Fang L-Y, Wang J and Shen Y-J (2009) Analysis of genetic diversity of Vitis by using ISSR markers. Acta Horticulturae 827: 125-130.

Zhang D, Martínez WJ, Johnson ES, Somarriba E, Phillips-Mora W, Astorga C, Mischke S and Meinhardt LW (2012) Genetic diversity and spatial structure in a new distinct Theobroma cacao L. population in Bolivia. Genetic Resources and Crop Evolution 59: 239-252.

Zietkiewicz E, Rafalski A and Labuda D (1994) Genome fingerprinting by simple sequence repeat (SSR)-anchored polymerase chain reaction amplification. Genomics 20: 176-183. 